\title{
Presence of antibodies against Toxoplasma gondii, Neospora caninum and Leishmania infantum in dogs from Piauí
}

Presença de anticorpos anti-Toxoplasma gondii, Neospora caninum e Leishmania infantum em cães do Piauí

Marcos Gomes Lopes ${ }^{1}$; Ivete Lopes Mendonça ${ }^{1}$; Kleber Portela Fortes ${ }^{1}$;

Marcos Amaku²; Hilda de Fátima Jesus Pena²; Solange Maria Gennari ${ }^{2 *}$

${ }^{1}$ Laboratório de Sanidade Animal, Departamento de Clínica Veterinária e Cirurgia, Centro de Ciências Agrárias,

Universidade Federal do Piauí - UFPI

${ }_{2}^{2}$ Departamento de Medicina Veterinária Preventiva e Saúde Animal, Faculdade de Medicina Veterinária e Zootecnia,

Universidade de São Paulo - USP

Received July 26, 2010

Accepted February 24, 2011

\begin{abstract}
This study aimed to evaluate the presence of antibodies against Neospora caninum, Toxoplasma gondii and Leishmania infantum in dogs attended at the Veterinary Hospital of the Federal University of Piauí, Northeastern Brazil, where there are no reports of the occurrence of $N$. caninum and T. gondii in dogs. Serum samples from 530 dogs of genders, different ages and breeds from the municipality of Teresina and nearby towns were analyzed using three indirect fluorescent antibody tests, each one targeting one of the three agents. The associations between the parasites and gender, breed and age of the dogs were assessed by the chi-square test $(\mathrm{p}>0.05)$. The occurrence of antibodies to N. caninum, T. gondii and $L$. infantum was 3.2, 18.0 and $78.1 \%$, respectively. Toxoplasma gondii was more frequently found in older dogs $(\mathrm{p}<0.05)$ whereas $L$. infantum was more common in animals aged between 1 to 3 years $(\mathrm{p}<0.05)$. In order to evaluate potential associations between the presence of anti- $N$. caninum and anti-T. gondii antibodies and Leishmania infection, 240 dogs were selected (120 positive and 120 negative for Leishmania spp.), based on serological and parasitological diagnoses. No association was found between Leishmania spp. and the coccidian parasites ( $p>0.05)$. The results confirm the exposure of dogs to these parasites in the State of Piauí.
\end{abstract}

Keywords: Leishmania infantum, Toxoplasma gondii, Neospora caninum, Piauí, dogs.

\section{Resumo}

Este estudo teve como objetivo avaliar a presença de anticorpos contra Neospora caninum, Toxoplasma gondii e Leishmania infantum em cães atendidos no Hospital Veterinário da Universidade Federal do Piauí, Teresina, Piauí, onde não há relatos de ocorrência de N. caninum e T. gondii em cães. Amostras de soro de 530 cães de ambos os sexos, diferentes idades e raças do município de Teresina e cidades vizinhas, foram analisados utilizando três testes de imunofluorescência indireta para cada um dos três agentes. Associação entre os parasitas e o sexo, a raça e a idade dos cáes foram analisadas pelo teste do qui-quadrado $(\mathrm{p}>0,05)$. Ocorrência de anticorpos para $N$. caninum, T. gondii e L. infantum foi de 3,2, 18,0 e 78,1\%, respectivamente. Toxoplasma gondii foi mais freqüente em cães mais velhos ( $p>0,05$ ), enquanto $L$. infantum apresentou maior freqüência em animais com idade entre um e três anos ( $>$ > 0,05). Para avaliar possíveis associaçóes entre a presença de anticorpos anti- $N$. caninum e anti- $T$. gondii com infecçáo por Leishmania, outros 240 cáes foram selecionados, sendo 120 positivos e 120 negativos para leishmaniose, por métodos parasitológicos e sorológicos. Nenhuma associação foi encontrada entre a positividade para Leishmania e para os coccídios ( $\mathrm{p}>0,05)$. Os resultados confirmam a exposição de cães a esses parasitas no Estado do Piauí.

Palavras-chave: Leishmania infantum, Toxoplasma gondii, Neospora caninum, Piauí, cáes.

\footnotetext{
*Corresponding author: Solange M. Gennari

Departamento de Medicina Veterinária Preventiva e Saúde Animal,

Faculdade de Medicina Veterinária e Zootecnia,

Universidade de São Paulo - USP, Av. Prof. Orlando M. de Paiva, 87,

Cidade Universitária, CEP 05508-270, São Paulo - SP, Brazil;

e-mail: sgennari@usp.br
} 


\section{Introduction}

Neospora caninum is an intracellular protozoan with a wide host range and has emerged as a serious disease in cattle and dogs worldwide. Dogs are the definitive hosts, and neosporosis is a major cause of abortion in cattle (DUBEY et al., 1988).

Toxoplasmosis is caused by Toxoplasma gondii, an obligate intracellular and opportunistic parasite that affects all warmblooded animals including humans. Due to the high rates of naturally infected dogs by $T$. gondii and its correlation with immunosuppressive diseases such as canine distemper and leishmaniasis (MORETTI et al., 2002), T. gondii is of great importance in this species. Although dogs are not definitive hosts of $T$. gondii they might eventually contribute to its mechanical dissemination (FRENKEL; PARKER, 1996; LINDSAY et al., 1997, SCHWARZ et al., 2005).

Leishmaniosis is caused by a digenetic parasite and can have different clinical forms, depending on the Leishmania species involved (GONTIJO; CARVALHO, 2003). In Brazil, the visceral form is caused by Leishmania infantum (= L. chagasi) of the Leishmania donovani complex (GONTIJO; MELLO, 2004). Dogs play an important role in the epidemiology of this disease, acting as reservoirs of the parasite. Even asymptomatic dogs can transmit the infection to humans through an arthropod vector (MOSHFE et al., 2009).

Recent studies conducted in Brazil have shown variation in the prevalence of anti-T. gondii, anti-N. caninum and anti-Leishmania spp. antibodies in dogs from different regions, ranging from 21.3 to $76.4 \%$ for T. gondii (SOUZA et al., 2003; CAÑ́́NFRANCO et al., 2004; AZEVEDO et al., 2005; DUBEY et al., 2007), 8.3 to $28.3 \%$ for $N$. caninum (reviewed by GENNARI et al., 2002, 2004; AZEVEDO et al., 2005; FIGUEREDO et al., 2008) and 3.4 to $51.5 \%$ for Leishmania spp. (DANTAS-TORRES et al., 2006; ABREU-SILVA et al., 2008; ALMEIDA et al., 2009). However, there were no studies of these parasites in dogs in the Northeastern State of Piauí.

The aim of this study was to evaluate the presence of antibodies anti-N. caninum, anti-T. gondii and anti-L. infantum in dogs and risk factors associated with these infections.

\section{Material and Methods}

A total of 530 serum samples from a collection of sera of the Laboratory of Animal Health at the Federal University of Piauí (UFPI), Teresina, Piauí, was examined from January 2007 to December 2008. Dogs with clinical signs of leishmaniosis were randomly selected. The dogs were of both genders (306 males and 224 females), aged two months to 12 years and of different breeds. The animals were from the urban area of the capital city Teresina and nearby towns.

An additional set of 240 serum samples from dogs with the same characteristics of the previous samples, and also collected in the UFPI Veterinary Hospital, was analyzed. However, these samples were collected in 2009 and half of them (120 dogs) were parasitologically and serologically positive for leishmaniosis and the other half were negative. These dogs were used to evaluate potential associations between the presence of antibodies against $N$. caninum and T. gondii in Leishmania spp.-positive and negative groups.

Antibodies against $N$. caninum and $T$. gondii were determined by indirect immunofluorescence antibody test (IFAT) according to Dubey et al. (1988) and Camargo (1974), respectively. The sera were tested at a start dilution of 1:50 for $N$. caninum and 1:16 for $T$. gondii. In all reactions, positive and negative control sera were used.

The detection of antibodies against Leishmania spp. was performed according to the instructions of the manufacturer of IFAT-canine visceral leishmaniosis kit (Bio-Manguinhos, FIOCRUZ, MS, Brazil), and samples with titers $\geq 40$ were considered positive.

For the parasitological diagnosis bone marrow and popliteal lymph node aspiration smears were prepared on slides, fixed with methanol and stained with Giemsa. The samples were analyzed using a 100× magnification for observation of amastigotes forms.

Lymph node and/or bone marrow tissues were punctured and aliquots of these tissues were seeded into tubes containing $2 \mathrm{~mL}$ of NNN medium (modified Novy-McNeal-Nicolle blood agar), added to Schneider medium for observation of promastigotes growth from Day 5 of cultivation (MONTEIRO et al., 1994).

For the statistical analyses, the chi-square test with a significance level of $5 \%$ was used to assess the associations between the occurrence of antibodies against each of the agents studied with gender, age and presence of co-infection. The associations between the presence of antibodies against $T$. gondii and $N$. caninum in dogs positive and negative to Leishmania spp. were analyzed using the same test.

\section{Results and Discussion}

The analysis of the 530 serum samples showed the following occurrence of antibodies: $18.0 \%$ (100/530) anti-T. gondii, $3.2 \%(17 / 530)$ anti-N. caninum and $77.9 \%(413 / 530)$ anti-Leishmania spp.

No association was found ( $p>0.05$ ) between the occurrence of anti- $N$. caninum, Leishmania spp. and T. gondii antibodies with gender and breed of the animals examined. These results are consistent with other Brazilian studies (SOUZA et al., 2002; TEIXEIRA et al., 2006) suggesting that male and female dogs have the same risk of infection by these parasites, although the level of exposure of males and females can also vary according to characteristics of each dog population (DANTAS-TORRES et al., 2006).

Regarding age, those dogs positive to $T$. gondii were more frequently older $(\mathrm{p}<0.05)$ while Leishmania spp. infection was most commonly seen in animals aged between one to two years ( $\mathrm{p}<0.05)$ as shown in Table 1. Cañón-Franco et al. (2004) found in Monte Negro, Rondônia, Northern Brazil, that the occurrence of anti-T. gondii antibodies increased with animal age and they reported a high rate of postnatal exposure. This is similar to that seen in the present study, in which higher relative rates of infection were found with increasing dog age, however this increase was only significant in the group of dogs aged nine years $(\mathrm{p}=0.05)$.

Although Piauí is an endemic area of leishmaniosis, there have been few studies in animal or humans (COSTA et al., 1990). An 
Table 1. Occurrence (\%) of antibodies against Leishmania spp., Neospora caninum and Toxoplasma gondii by age group in 530 dogs attended at the Veterinary Hospital, Federal University of Piauí, Northeastern Brazil, January 2007 to December 2008.

\begin{tabular}{ccccc}
\hline Age group (years old) & Total examined & \multicolumn{3}{c}{ Number (No.) positive dogs (\%) } \\
\cline { 3 - 5 } & & Leishmania spp. & N. caninum & T.gondii \\
\hline$<1$ & 89 & $64(71.91)^{\mathrm{a}}$ & $03(3.51)^{\mathrm{a}}$ & $12(12.50)^{\mathrm{a}}$ \\
$\geq 1$ to $<3$ & 167 & $144(86.22)^{\mathrm{b}}$ & $11(6.63)^{\mathrm{a}}$ & $22(12.65)^{\mathrm{a}}$ \\
$\geq 3$ to $<5$ & 146 & $116(79.45)^{\mathrm{a}}$ & $01(0.69)^{\mathrm{a}}$ & $30(20.83)^{\mathrm{a}}$ \\
$\geq 5$ to $<9$ & 97 & $70(72.16)^{\mathrm{a}}$ & $01(1.05)^{\mathrm{a}}$ & $23(24.20)^{\mathrm{a}}$ \\
$\geq 9$ & 31 & $19(61.29)^{\mathrm{a}}$ & $01(3.45)^{\mathrm{a}}$ & $13(41.38)^{\mathrm{a}}$ \\
Total & 530 & $413(77.92)$ & $17(3.20)$ & $100(18.00)$ \\
\hline
\end{tabular}

Different letters in the same column $\mathrm{p} \leq 0.005$.

Table 2. Number (No.) of positive (+) and negative dogs (-) to antiNeospora caninum, anti-Toxoplasma gondii and anti-Leishmania spp. antibodies and rates of potential co-infections.

\begin{tabular}{ccc} 
Status & $\begin{array}{c}\text { Number } \\
\text { (No.) dogs }\end{array}$ & Rate (\%) \\
\hline Leishmania -, T. gondii -, N. caninum - & 95 & 17.9 \\
Leishmania -, T. gondii -, N. caninum + & 0 & 0.0 \\
Leishmania -, T. gondii +, N. caninum - & 22 & 4.15 \\
Leishmania +, T. gondii -, N. caninum - & 321 & 60.5 \\
Leishmania -, T. gondii +, N. caninum + & 0 & 0.0 \\
Leishmania +, T. gondii +, N. caninum - & 75 & 14.1 \\
Leishmania +, T. gondii -, N. caninum + & 14 & 2.6 \\
Leishmania +, T. gondii +, N. caninum + & 3 & 0.5 \\
\hline
\end{tabular}

Table 3. Occurrence (\%) of anti-T. gondii and anti-N. caninum antibodies in positive (+) and negative (-) dogs for Leishmania spp. by parasitological and serological methods.

\begin{tabular}{lcccccc}
\hline & $\begin{array}{c}\text { Number } \\
\text { (No.) }\end{array}$ & \multicolumn{2}{c}{ Toxoplasma gondii } & & \multicolumn{2}{c}{ Neospora caninum } \\
\cline { 3 - 4 } & & + & - & & + & - \\
\hline Leishmania & 120 & 23 & 97 & & 03 & 117 \\
$(+)$ & & $(19.16 \%)$ & $(80.83 \%)$ & & $(02.50 \%)$ & $(97.50 \%)$ \\
Leishmania & 120 & 18 & 102 & & 04 & 116 \\
$(-)$ & & $(15.00 \%)$ & $(85.00 \%)$ & & $(03.33 \%)$ & $(96.60 \%)$ \\
Total & 240 & 41 & 199 & & 07 & 233 \\
& & $(17.08 \%)$ & $(82.91 \%)$ & $(02.91 \%)$ & $(97.08 \%)$ \\
\hline
\end{tabular}

association was also found between age and seropositivity of dogs to Leishmania spp., with high occurrence in dogs aged between 1 to 3 years $(p<0.05)$. In Araçatuba, São Paulo, Southeastern Brazil, Gennari et al. (2006) reported an weak association ( $p=0.038)$ with a higher number of 4-year-old positive dogs and Dantas-Torres et al. (2006), in Pernambuco, Northeastern Brazil, reported higher occurrence in dogs younger than 1 year.

No association was found between co-infection by Leishmania spp. and T. gondii and by T. gondii and N. caninum $(\mathrm{p}>0.05)$. However an association between co-infection by Leishmania spp. and $N$. caninum $(\mathrm{p}<0.05)$ was seen with all $17 N$. caninum-positive dogs that were also Leishmania spp.positive (Table 2). Gennari et al. (2006), in a study with dogs from Araçatuba, São Paulo, Southeastern Brazil, and Cringoli et al. (2002), with dogs from Southern Italy, also found an association between $L$. infantum and $N$. caninum antibodies.
As the samples in the present study were from dogs with suspected leishmaniosis, a new set of samples was analyzed, this time with the same number of positive $(n=120)$ and negative dogs ( $\mathrm{n}=120)$. This new sampling was carried out to confirm the results obtained in the analysis of associations between Leishmania spp. and the coccidian parasites. The results from these samples were different from those first analyzed and no differences were found ( $\mathrm{p}>0.05$ ) between the proportions of positive dogs for $T$. gondii and $N$. caninum in the group of Leishmania spp.-positive and negative dogs (Table 3), which corroborates the results reported by Valadas et al. (2010) in the State of Pará, Northern Brazil. However, the rates of $T$. gondii (17\%) and N. caninum (2.9\%) antibodies found in these 240 new samples were similar $(\mathrm{p}>0.05)$ to those found for T. gondii (18\%) and N. caninum (3.2\%) in our first evaluation.

There were other studies showing the presence of dogs positive to these parasites in other Northeastern States of Brazil. However, this is the first confirmation that dogs from Piauí were also exposure to T. gondii, N. caninum and Leishmania spp. Further studies focusing on the epidemiological aspects of these parasites in the region are necessary for better control them.

\section{References}

ABREU-SILVA, A. L. et al. Soroprevalência, aspectos clínicos e bioquímicos da infecção por Leishmania em cáes naturalmente infectados e fauna de flebotomíneos em uma área endêmica na ilha de São Luís, Maranhão, Brasil. Revista Brasileira de Parasitologia Veterinária, v. 17, Supl.1, p. 197-203, 2008.

ALMEIDA, A. B. P. F. et al. Inquérito soroepidemiológico de leishmaniose canina em áreas endêmicas de Cuiabá, estado de Mato Grosso. Revista da Sociedade Brasileira de Medicina Tropical, v. 42, n. 2, p. 156-159, 2009.

AZEVEDO, S. S. et al. Seroepidemiology of Toxoplasma gondii and Neospora caninum in dogs from the state of Paraíba, northeast region of Brazil. Research in Veterinary Science, v. 79, n. 1, p. 51-56, 2005. PMid:15894024. http://dx.doi.org/10.1016/j.rvsc.2004.10.001

CAMARGO, M. E. Introdução às técnicas de imunofluorência. Revista Brasileira de Patologia Clínica, v. 10, n.4, p. 143-171, 1974.

CAÑÓN-FRANCO, W. A. et al. Occurrence of anti-Toxoplasma gondii antibodies in dogs in the urban area of Monte Negro, Rondônia, Brazil. Veterinary Research Communications, v. 28, n. 2, p. 113-118, 2004. 
COSTA, C. H. N.; PEREIRA, H. F.; ARAÚJO, M. V. Epidemia de leishmaniose visceral, no estado do Piauí, Brasil, 1980- 1986. Revista Saúde Publica, v. 24, n. 5, p. 361-372, 1990.

CRINGOLI, G. et al. Serological survey of Neospora caninum and Leishmania infantum co-infection in dogs. Veterinary Parasitology, v. 106, n. 4, p. 307-313, 2002. http://dx.doi.org/10.1016/S03044017(02)00114-0

DANTAS-TORRES, F.; BRITO M. E. F.; BRANDÁO-FILHO, S. P. Seroepidemiological survey on canine leishmaniosis among dogs from an urban area of Brazil. Veterinary Parasitology, v. 140, n. 1-2, p. 54-60, 2006. PMid:16621286. http://dx.doi.org/10.1016/j.vetpar.2006.03.008

DUBEY, J. P. et al. Newly recognized protozoan disease of dogs. Journal of the American Veterinary Medical Association, v. 192, n. 9 , p. 1269-1285, 1988.

DUBEY, J. P. et al. Diverse and atypical genotypes identified in Toxoplasma gondii from dogs in São Paulo, Brazil. Journal of Parasitology, v. 93, n. 1, p. 60-64, 2007. PMid:17436942. http://dx.doi.org/10.1645/GE-972R.1

FIGUEREDO, L. A. et al. Ocurrence of antibodies to Neospora caninum and Toxoplasma gondii in dogs from Pernambuco, northeast Brazil. Veterinary Parasitology, v. 157, n. 1-2, p. 9-13, 2008.

FRENKEL, J. K.; PARKER, B. B. An apparent role of dogs in the transmission on of Toxoplasma gondii: The probable importance of xenosmophilia. Annals of the New York Academy of Sciences, v. 79, n. 1, p. 402-407, 1996. PMid:8784520. http://dx.doi. org/10.1111/j.1749-6632.1996.tb53546.x

GENNARI, S. M. Neospora caninum no Brasil: situação atual da pesquisa. Revista Brasileira de Parasitologia Veterinária, v. 13, supl. 1, p. 23-28, 2004.

GENNARI, S. M. et al. Occurrence of Neospora caninum antibodies in sera from dogs of the city of São Paulo, Brazil. Veterinary Parasitology, v. 106, n. 2, p.177-179, 2002. http://dx.doi.org/10.1016/S03044017(02)00052-3

GENNARI, S. M. et al. Presence of anti-Neospora caninum and Toxoplasma gondii antibodies in dogs with visceral leishmaniosis from the region of Araçatuba, São Paulo, Brazil. Brazilian Journal of Veterinary Research and Animal Science, v. 43, n. 5, p. 613-619, 2006.
GONTIJO, B., CARVALHO, M. L. R. Leishmaniose tegumentar americana. Revista da Sociedade Brasileira de Medicina Tropical, v. 36, n. 1, p. 71-80, 2003. http://dx.doi.org/10.1590/S1415$790 \times 2004000300011$

GONTIJO, C. M. F., MELO, M. N. Leishmaniose visceral no Brasil: quadro atual, desafios e perspectivas. Revista Brasileira de Epidemiologia, v. 7, n. 3, p. 338-349, 2004.

LINDSAY, D. S. et al. Mechanical transmission of Toxoplasma gondii oocysts by dogs. Veterinary Parasitology, v. 73, n. 1-2, p. 27-33, 1997. http://dx.doi.org/10.1016/S0304-4017(97)00048-4

MONTEIRO, P. S.; LACERDA, M. M.; ARIAS, J. R. Controle da leishmaniose visceral no Brasil. Revista da Sociedade Brasileira de Medicina Tropical, v. 27, sulp. 3, p. 67-72, 1994.

MORETTI, L. D. et al. Toxoplasmose em cães co-infectados com o vírus da cinomose. Semina: Ciências Agrárias, v. 23, n. 1, p. 85-91, 2002.

MOSHFE, A. et al. Canine visceral leishmaniasis: asymptomatic infected dogs as a source of $L$. infantum infection. Acta Tropica, v. 112, n. 2, p.101-105, 2009. PMid:19595664. http://dx.doi.org/10.1016/j. actatropica.2009.07.004

SCHWARZ, J. A. et al. A novel rhoptry protein in Toxoplasma gondii bradyzoites and merozoites. Molecular and Biochemical Parasitology, v. 144, n. 2, p. 159-166, 2005.

SOUZA, S. L. P. et al. Prevalence of Neospora caninum antibodies in dogs from dairy cattle farms in Parana, Brazil. Journal of Parasitology, v. 88 , n. 2 , p. 408-409, 2002

SOUZA, S. L. P. et al. Occurrence of Toxoplasma gondii antibodies in sera from dogs of the urban and rural areas from Brazil. Revista Brasileira de Parasitologia Veterinária, v. 12, n. 1, p. 1-3, 2003.

TEIXEIRA, W. C. et al. Freqüência de cães reagentes para Neospora caninum em São Luís, Maranhão. Arquivo Brasileiro de Medicina Veterinária e Zootecnia, v. 58, n. 4, p. 685-687, 2006. http://dx.doi. org/10.1590/S0102-09352006000400038

VALADAS, S. et al. Occurrence of antibodies anti-Neospora caninum, anti-Toxoplasma gondii and anti-Leishmania chagasi in serum of dogs from Pará State, Amazon Brazil. Parasitology Research, v. 107, n. 2, p. 453-457, 2010. PMid:20445991. http://dx.doi.org/10.1007/s00436010-1890-2 